\title{
Quality control in cervical cytology
}

\author{
O. A. N. HUSAIN, E. BLANCHE BUTLER, D. M. D. EVANS ${ }^{1}$, \\ J. ELIZABETH MACGREGOR, AND R. YULE
}

From St Stephen's and Charing Cross Hospitals, London, St Mary's Hospital, Manchester, St David's Hospital, Cardiff, the University of Aberdeen, and the Christie Hospital and Holt Radium Institute, Manchester

SYNOPSIS From surveys conducted by the authors it is concluded that the best and most acceptable quality control methods in cytology are those from within the laboratory. Most of these have results . which can be reported centrally. Where the overall control and codes of practice are high, there the results are the most reliable, as sources of error from whatever cause are quickly brought to light. These conclusions are illustrated by data from the five centres and correlated in the tables.

The problem of quality control in cytology is complex. In the first place it must be quite clear what quality is being controlled. Essentially, it is the accuracy of diagnosis of cancer or precancer; or, conversely, the certainty of its absence. There are, however, many shades of grey in this diagnosis due to the need to recognize the wide range of dysplasia and carcinoma in situ as well as invasive cancer. In addition, there is the need to appreciate indirect evidence of neoplasia such as unexplained cellular debris or unusual hormonal patterns, as these features can contribute to the quality of the final report,

Cytopathology, like histopathology, is a subjective discipline. In the final analysis all cytological reports are the opinion of one person and are in turn monitored by the opinion of a colleague reporting on histological sections from the same patient. To maintain a reasonable uniformity of quality of cytology reports throughout the country, proper training of cytopathologists is of first importance, but it is also important that all those involved in cytology should be aware of the areas of potential error which can lead to inaccuracy.

Control of the quality of collection, preparation, screening, and interpretation is of importance in all branches of cytology, but this paper deals primarily

\footnotetext{
${ }^{1}$ This is a compilation of data from a lecture given to the Royal College of Pathologists on 2 May 1973 by O.A.N.H. and a symposium on quality control given at the British Society for Clinical Cytology meeting on 28 September 1973 in the Hammersmith Hospital by all authors. A paper by Evans et al presented elsewhere in this journal was embodied in the symposium.

Received for publication 10 September 1974
}

with the problem of detection of malignant and premalignant disease of the uterine cervix. A number of surveys have demonstrated the wide range of error rates for this condition where the false negative rate varies from $1 \cdot 1$ to $30 \%$ (table I). Table I demonstrates not only the wide scatter of results presented in the literature but also the range of lesions being assessed, the various methods of sample collection, and the very wide variety of methods used to calculate the results. All this makes comparisons difficult. False negative rates are usually underestimated because they are only discovered when abnormal histology or an abnormal smear follows a previous negative smear. The mobility of populations and failure of follow up can prevent this information reaching the laboratory which put out the false negative report and so prevent complete accuracy when false negative rates are circulated. It is only when a second smear is taken as in the Christie Hospital series that the resulting figures are a true measure of the false negative rate. Errors can occur at all stages and these will be considered under the following headings: (1) biological variability; (2) collection of samples (a, site, b, sampling method); (3) laboratory procedures ( $a$, processing, b, screening, $c$, interpretation).

\section{Biological Variability}

Failure of exfoliation of malignant cells is a well documented phenomenon (Richart, 1964). This can occur when specimens are taken with every care and on examination the smear fulfils all criteria 


\begin{tabular}{|c|c|c|}
\hline Survey & Percentage False Negative Rate & \\
\hline Graham and Meigs (1949) & Vaginal aspirate & $10 \cdot 0$ \\
\hline Scheffey (1949) & & $30 \cdot 0$ \\
\hline & Reduced by multiple screening to & $17 \cdot 6$ \\
\hline Achenbach et al (1951) & Vaginal aspirate & $28 \cdot 0$ \\
\hline Cuyler et al (1951) & Dysplasia-invasive carcinoma & $9 \cdot 2-12 \cdot 8$ \\
\hline Reagan and Hicks (1953) & & $5 \cdot 0$ \\
\hline Fidler et al (1957) & Squamous cell carcinoma & $6 \cdot 5$ \\
\hline Friedell et al (1960) & Vaginal aspirate & $19 \cdot 0$ \\
\hline & Cervical os aspirate & $11 \cdot 0$ \\
\hline Soule and Dahlin (1960) & & $2 \cdot 4$ \\
\hline Richart (1964) & Initial smear positive & $1 \cdot 1$ \\
\hline & Overall & $1 \cdot 4-2 \cdot 8$ \\
\hline & Gross invasive carcinoma & $7 \cdot 0$ \\
\hline Silbar and Woodruff (1966) & & $18 \cdot 0$ \\
\hline & Reviewed by Butler and Frost (negative) & 2.4 \\
\hline & Slight cell atypia & 3.6 \\
\hline Evans and Sanerkin (1970) & Five different centres & $3 \cdot 0-26 \cdot 0$ \\
\hline Yule (1973) & & $12 \cdot 7$ \\
\hline
\end{tabular}

Table I False negative rates in screening for cervical cancer

for a satisfactory specimen. There can be variability in exfoliation when positive and negative cervical smears alternate and this also occurs in the case of sputum, urine, and body cavity fluid cytology.

An embarrassing and not uncommon cause of failure of exfoliation is found in some cases of overt carcinoma of the cervix. In these cases necrotic tissue can prevent exfoliation and a high proportion of the smears are in fact unsatisfactory (table II). Failure of exfoliation is more common in postmenopausal women as was found by Butler and Frost in their review of material reported by Silbar and Woodruff (1966). In this series $12 \%$ of women with false negative smears were postmenopausal, while of the women with positive or suspicious smears only $5.4 \%$ were postmenopausal (Butler, 1973).

\begin{tabular}{lrl}
\hline Original Report & No. & $\begin{array}{l}\text { Unsatisfactory } \\
\text { on Review (\%) }\end{array}$ \\
\hline Positive & $136(87 \%)$ & 22 \\
Negative & $20(13 \%)$ & 75 \\
Total & $156(100 \%)$ & - \\
\hline
\end{tabular}

Table II Review of cytology in clinical cases of invasive carcinoma (Aberdeen)

\section{Collection of Samples}

SITE

Material for the detection of cervical cancer can be collected by cervical scrape, vaginal aspiration, or with an irrigation pipette. It is reasonable to expect that detection rates will be best when a cervical scrape smear is taken, and this was confirmed by
Macgregor, Fraser, and Mann (1966). Wied (1955) 오 found that with carcinoma in situ of the cervix the $\vec{\nabla}$ vaginal aspirate contained only 2.5 abnormal cells $\mathbb{D}$

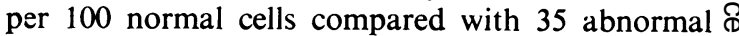
cells in the ectocervical scrape, and 110 abnormal cells in the endocervical swab smear. Choice of a $\stackrel{\mathbb{D}}{-}$ method which gives maximum exfoliation becomes $\vec{\varphi}$ even more important if earlier lesions such dysplasia are to be detected. Husain (1970) found that the irrigation pipette detected 65 to $70 \%$ cases with dysplasia and $85 \%$ of cases with carcinoma in situ in comparison with $100 \%$ detection using a cervical scrape smear in the same cases. When numbers of abnormal cells were counted in smears collected by the two methods the rates were between 10 and 50 times less using the irrigation pipette (Husain, unpublished results).

In the Aberdeen series (J.E.M.) a comparison was made of the effectiveness of the detection of cancer and precancer of the cervix using cervical and vaginal smears (table III). Both smears were equally positive in $19.2 \%$ of the 61 cases studied but in $69 \%$ the cervical smear contained more abnormal cells while the vaginal smear was the more abnormal in only $6.9 \%$ of cases.

Other workers have described similar results.

\begin{tabular}{lrr}
\hline & No. \\
\hline Cervical smear more positive than vaginal & 42 & $(69.0 \%)$ \\
Cervical smear less positive than vaginal & 4 & $(6.9 \%)$ \\
Cervical smear as positive as vaginal & 12 & $(19.2 \%)$ \\
Both smears unsatisfactory & 3 & $(4.9 \%)$ \\
Total & $61(100.0 \%)$ \\
\hline
\end{tabular}

Table III Comparison of vaginal and cervical smears in cases of carcinoma in situ and invasive cervical cancer (Aberdeen) 
Richart and Valliant (1965) found a $45 \%$ false negative rate for vaginal pool aspirations and only $4 \%$ for smears from the external os. Frost (1969) described a false negative rate of $42 \%$ for invasive cancer and $69 \%$ for carcinoma in situ using vaginal pool material while the comparable rates were $0 \%$ and $18 \%$ when a cervical scrape smear was used.

There are, however, advantages in examining vaginal smears, particularly in older women, as these also are at risk for endometrial cancer. Simon, Durfee, and Ricci (1955) found that in cases of adenocarcinoma of the endometrium the report was positive or suspicious in only $41.4 \%$ of cases when a cervical smear was used, while $75.8 \%$ were recognized when a vaginal aspiration smear was taken. The vaginal aspiration smear may also be of value in cases in which cervical cancer arises in the canal, particularly following cone biopsy which can cause stenosis of the external os. Frost (1967) recommends a combined cervical and vaginal smear while Wied and Bahr (1959) prefer the triple smear in which material from vagina, ectocervix, and endocervix is placed in succession on one slide. These methods have the advantage that the workload of the laboratory is not increased but they have never become popular in Britain. It is not practicable economically to require cervical and vaginal smears on all patients, and in most premenopausal cases a good cervical smear is sufficient as a routine procedure. It might, however, be useful to take a vaginal aspiration smear as well in certain cases such as from all postmenopausal women as well as from women with intermenstrual, postcoital, or postmenopausal bleeding and women being followed after cone biopsy of the cervix.

\section{SAMPLING METHOD}

Premalignant lesions of the cervix usually arise in the neighbourhood of the squamo-columnar junction in the area known as the transformation zone, and in the histological specimen many lesions appear to be predominantly in the endocervical canal. The cervical scrape should include these areas and the spatula should be rotated firmly through the $360^{\circ}$ of the circumference of the cervix. Proper exposure of the cervix, preferably with the patient in the dorsal position, is essential and better exposure results from the use of a bivalve speculum as this everts the cervix to expose the transformation zone and lower end of the cervical canal. Difficulties arise when patients are obese or have a lax vaginal wall. In women with senile vaginitis or following pelvic floor repair it may be difficult to pass a speculum and a vaginal aspiration smear or irrigation specimen may be the only solution.

In Britain the traditional Ayre's spatula is commonly used to collect cervical smears. There has been concern for some years as to whether this is the most suitably shaped spatula which could be devised. In older women the squamo-columnar junction retreats up the cervical canal and, particularly when the external os is narrow, it is not possible to reach the columnar epithelium even when the knuckle-shaped end of the spatula is used. Smears in these cases contain no endocervical columnar cells and are unsatisfactory on strict criteria (Gondos, Marshall, and Ostergard, 1972). (A subcommittee of the British Society for Clinical Cytology is studying and comparing the efficacy of various patterns of spatulae in an attempt to improve the design.)

The collection of a good smear is not complete until the material is spread evenly on a glass slide and fixed immediately. Delay in fixation allows the smear to dry and with the Papanicolaou method of staining this results in artefacts which may make it impossible to interpret the smear.

\section{ESTIMATE OF FALSE NEGATIVE ERROR}

This first section of the paper has dealt with matters which are usually outside the control of the laboratory, but the work done by one of us at the Christie Hospital, Manchester (R.Y.) demonstrates that it is an important area when the reliability of a single Ayre's smear is considered.

Quality control of cervical cytology in the Christie Hospital and Holt Radium Institute has taken the form of a randomized recall of $10 \%$ of women, whose first smears were reported as normal and satisfactory, after an interval of three months. The computerized records system makes it possible to do this with comparative ease. As the interval between the two smears is so short, the second smear acts as a check or control on the first: it is assumed that the 'positive smear state' will not arise anew during such a short interval. An analysis of 14437 women who responded to the request to have a further test at three months is given in tables IV and V.

Table IV shows that of 25 smears diagnosed as positive at the second screening, where the first had been reported as negative, review of the first smear revealed that nine were in fact positive; these were screening errors or 'false negative' reports. The other

\begin{tabular}{lcl}
\hline Review of First Smear & No. & Rate/1000 \\
\hline Negative & 16 & $1 \cdot 11$ \\
Positive & 9 & $0 \cdot 60$ \\
Total & 25 & $1 \cdot 71$
\end{tabular}

Table IV Review of first smear in cases with positive second smear (Christie Hospital, Manchester) $(n=14437)$ 
16 were confirmed as negative and satisfactory. In these latter cases the 'errors' are regarded as being due to failure on the part of the sampling or 'scraping technique' to place abnormal cells, present in that cervix, on the slide where they could have been seen. This is a total error rate of only 1.71 per 1000 smears examined, which seems acceptable, but when the 'missed positives' are considered as a percentage of the 'true positive' it presents another aspect to the analysis and much less comforting figures (table V).

\begin{tabular}{lcc}
\hline & No. & Rate/1000 \\
\hline Positive at first screening & 143 & 9.94 \\
'Missed' positives & 25 & 1.71 \\
'True' positives & 168 & 11.65 \\
Error rate & 25 of 168 & $14.9 \%$ \\
\hline
\end{tabular}

Table V 'Missed' positives considered as a percentage of 'true' positives (Christie Hospital, Manchester) $(n=14437)$

It is now apparent that perhaps as many as one in six of cytologically abnormal cervices will not be detected if reliance is placed on a single scrape. In this series, fortunately, no invasive carcinoma was missed, all of the lesions being classified histologically as severe dysplasia or carcinoma in situ: in this sense no harm came to these women. The implication needs no emphasis here, for it must be clear that the relative unreliability of the scrape smear must be taken into account in planning cytology services in future, especially in regard to the frequency of screening.

The criticism of a $10 \%$ recall is one of cost while the other policy of two tests being performed within three, six, or 12 months as a method of quality control is still an expensive way of a test testing a test. In Great Britain the national policy in cervical screening has been a five-yearly recall. In practice, however, many centres compromise by conducting a three-yearly recall in order that the more frequent tests overcome the inherent errors from whatever source. This is no longer smear quality control, but an attempt to minimize errors, which is the ultimate purpose.

\section{Laboratory Procedures}

\section{PROCESSING}

Cervical and vaginal smears are unlikely to suffer from processing faults if the staining schedule is satisfactory. Specimens from other sites are received in the laboratory as fresh material and in a wider consideration of quality control it would be necessary to lay down criteria to ensure the best possible methods of preparation for all types of specimens. The only real danger in the staining of fixed smears is the risk of cross-contamination. Frequent change of solutions is important and care is needed to be sure that slides are not put in the rack with the surfaces, on which the smear has been made, facing each other. Loss of material from cervical smears during processing is unusual but it is common from serous fluid, seminal fluid, and urine smears. It is therefore unwise to stain such material in batches with cervical smears. Barr, Powell, and Raffan (1970) placed serous fluid smears containing cells from an adenocarcinoma among simple albuminized slides in bulk staining slide baskets. They found $17 \%$ cross-contamination using an automatic staining machine and up to $30 \%$ when hand staining schedules were used. The remedy of an individual staining machine is yet to appear on $N$ the market, although one of us (O.A.N.H.) has $\mathrm{C}$ interested a number of manufacturers in this idea over the past nine years, suggesting outlines of construction.

\section{SCREENING}

The screening of cytology smears is a most important area for quality control and the training of the cytotechnician who does this work is as important $\vec{\theta}$ as the training of the pathologist who signs out the final report. In many laboratories the volume of work is such that most smears considered to be 'negative are seen only by an experienced cytotechnician although the histories and the reports are checked by the pathologist as credible and appropriate. This places considerable responsibility on the screener. In addition to recognizing any abnormality she must be fully aware of all the features which make a smear 'unsatisfactory' or, what is more difficult, be able to recognize a suboptimal sample.

The recent publication by the World Health $\overline{7}$ Organization states that: "Artefacts and preparations that are unsatisfactory for a variety of reasons such as drying and paucity of material are a recurring $\delta$ problem. Since attempts at interpreting such preparations often lead to diagnostic errors, they must be 0 rejected as unsatisfactory, and a repeat smear requested' (Riotton and Christopherson, 1973).

The ideal cervical smear, collected as described above, would be expected to be relatively free from $\Omega$ blood, leucocytes, and mucus, and should contain $N$ superficial and intermediate squamous cells and N endocervical columnar cells. In addition, in many $\sigma$ women, cells of the parabasal type-scraped from areas of squamous metaplasia in the transformation $\frac{}{\circ}$ zone-would be expected. These cells are sometimes $\stackrel{\infty}{\rightarrow}$ referred to as 'deep squamous cells' and the degree of maturity which they show depends on the $\overline{0}$ maturity of the squamous metaplasia. Thus, when the 


\begin{tabular}{|c|c|c|c|c|}
\hline & Hospital & Family Planning Association & L.H.A. & General Practice \\
\hline $\begin{array}{l}\text { Endocervical Cellularity ( } \%) \\
\text { No endocervicals } \\
\text { Up to } 1 \text { sheet }(20+\text { cells) } \\
2 \text { to } 10 \text { sheets } \\
11 \text { to } 20 \text { sheets } \\
\text { More than } 20 \text { sheets }\end{array}$ & $\begin{array}{r}51 \cdot 0 \\
10.2 \\
28.3 \\
8.3 \\
2.2\end{array}$ & $\begin{array}{r}55.2 \\
12.2 \\
24.6 \\
5.5 \\
2.5\end{array}$ & $\begin{array}{r}46.0 \\
9.0 \\
25.6 \\
9.6 \\
9.8\end{array}$ & $\begin{array}{r}53.1 \\
11.5 \\
23.6 \\
7.9 \\
3.9\end{array}$ \\
\hline $\begin{array}{l}\text { Percentage Epithelial Cell C } \\
\text { Less than } 10000 \\
10 \text { to } 20000 \\
20 \text { to } 40000 \\
\text { Over } 40000\end{array}$ & $\begin{array}{r}\text { cervix } \pm v c \\
18.0 \\
53.8 \\
20.8 \\
7.4\end{array}$ & $\begin{array}{r}\text { nears } \\
8 \cdot 0 \\
40.8 \\
25 \cdot 9 \\
25 \cdot 3\end{array}$ & $\begin{array}{l}16.6 \\
31.4 \\
27.6 \\
24.4\end{array}$ & $\begin{array}{l}14.4 \\
42.5 \\
24.6 \\
18.5\end{array}$ \\
\hline
\end{tabular}

Table VI Cellularity of specimen according to source (St Stephen's Hospital, London)

transformation zone is completely covered by mature metaplastic epithelium these immature squamous cells will not be seen. The total cell sample is also important and a minimum of what is acceptable needs to be assessed. A series of smears has been evaluated at St Stephen's Hospital, both for cell numbers and cell content, and the results are shown in table VI.

In this series squamous cells and endocervical cells were counted to compare the results in smears taken from different types of patient. On the minimal score that a sample of more than 10000 cells containing more than one sheet of endocervical columnar cells was acceptable, it was found with some concern that 50 to $80 \%$ of the smears taken from various patient categories could be classed as unsatisfactory (table VII). A similar study in Aberdeen showed endocervical columnar cells in only $28 \%$ of cases. These low figures might be expected in postmenopausal women, but they were also found in sexually mature women. In the Aberdeen series the matter was investigated further because numbers of deep squamous cells were also counted, as it was felt that the presence of these cells indicated that the smear had been taken from the transformation zone, the area where most in situ lesions arise. However, absence of endocervical columnar cells might also reflect failure to reach the endocervical canal and in consequence miss lesions in the canal (table VIII).

\begin{tabular}{|c|c|c|c|c|}
\hline \multirow[b]{2}{*}{$\begin{array}{l}\text { Endocervicals } \\
\text { No endocervicals } \\
\text { Deep cells } \\
\text { Superficial cells only } \\
\text { Unsatisfactory }\end{array}$} & \multicolumn{2}{|c|}{ Cervical Smears } & \multicolumn{2}{|c|}{ Vaginal Smears } \\
\hline & $\begin{array}{r}17 \\
37 \\
42 \\
12 \\
7\end{array}$ & $\begin{array}{l}(27 \cdot 8 \%) \\
(60.6 \%) \\
(68 \cdot 8 \%) \\
(19.6 \%) \\
(11.4 \%)\end{array}$ & $\begin{array}{l}\overline{-} \\
\overline{12} \\
32 \\
17\end{array}$ & $\begin{array}{l}- \\
\overline{(19 \cdot 6 \%)} \\
(52 \cdot 4 \%) \\
(27.8 \%)\end{array}$ \\
\hline
\end{tabular}

Table VIII Comparison of cells in cervical and vaginal smears in cases of carcinoma in situ and invasive carcinoma $(n=61)$ (Aberdeen)

The poor collection rates for endocervical cells found in these two centres indicates that it is not realistic to call all smears unsatisfactory if endocervical cells are absent but it is necessary to be aware of the problem and evaluate the smear using other criteria such as the presence of cells shed from areas of squamous metaplasia and the presence of endocervical mucus. The possibility of improvement with a better designed spatula has been discussed in a previous section.

The rate for unsatisfactory smears varies depending on the source of the smear, and the laboratory is in a position to advise those who collect smears and to discuss the techniques used so that the quality of the material received can be improved. In Aberdeen a comparison was made between smears sent from different clinical sources (table IX). The poorest samples came from postnatal and family planning clinics, probably due to the large number

\begin{tabular}{|c|c|c|c|c|c|c|c|c|c|c|c|c|c|c|c|c|}
\hline & \multicolumn{7}{|c|}{ Age Groups in Decades } & \multicolumn{2}{|l|}{ Parity } & \multicolumn{2}{|c|}{ Obstetric State } & \multicolumn{3}{|c|}{ Contraception } & \multicolumn{2}{|c|}{$\begin{array}{l}\text { Condition of } \\
\text { Cervix }\end{array}$} \\
\hline & & & & & & & & $\begin{array}{l}\text { Nullip- } \\
\text { arous }\end{array}$ & $\begin{array}{l}\text { Multip- } \\
\text { arous }\end{array}$ & Pregnant & $P / N$ & $\checkmark I U C L$ & $D$ Pill & Other & Erosion & Other \\
\hline $\begin{array}{l}\text { Class } \\
\text { Numbers } \\
\text { Satisfactory (\%) }\end{array}$ & $\begin{array}{l}N / S \\
29 \\
28\end{array}$ & $\begin{array}{l}10+ \\
87 \\
26\end{array}$ & $\begin{array}{c}20+ \\
833 \\
35\end{array}$ & $\begin{array}{c}30+ \\
458 \\
35\end{array}$ & $\begin{array}{c}40+ \\
334 \\
32\end{array}$ & $\begin{array}{c}50+ \\
195 \\
39\end{array}$ & $\begin{array}{ll}60+70+ \\
53 & 11 \\
45 & 45\end{array}$ & $\begin{array}{r}728 \\
30\end{array}$ & $\begin{array}{r}1272 \\
37\end{array}$ & $\begin{array}{r}115 \\
26\end{array}$ & $\begin{array}{r}190 \\
32\end{array}$ & $\begin{array}{r}124 \\
47\end{array}$ & $\begin{array}{r}572 \\
27\end{array}$ & $\begin{array}{r}1304 \\
37\end{array}$ & $\begin{array}{r}158 \\
46\end{array}$ & $\begin{array}{r}1842 \\
34\end{array}$ \\
\hline
\end{tabular}

Table VII Validity of sample $(n=2000)$ (St Stephen's Hospital, London $)^{1}$

${ }^{1} \mathrm{Minimum}$ of 10000 epithelial cells and 1 to 10 sheets of endocervical cells per sample present, cervical and/or vaginal smears (one sheet $=$ about 20 cells). 


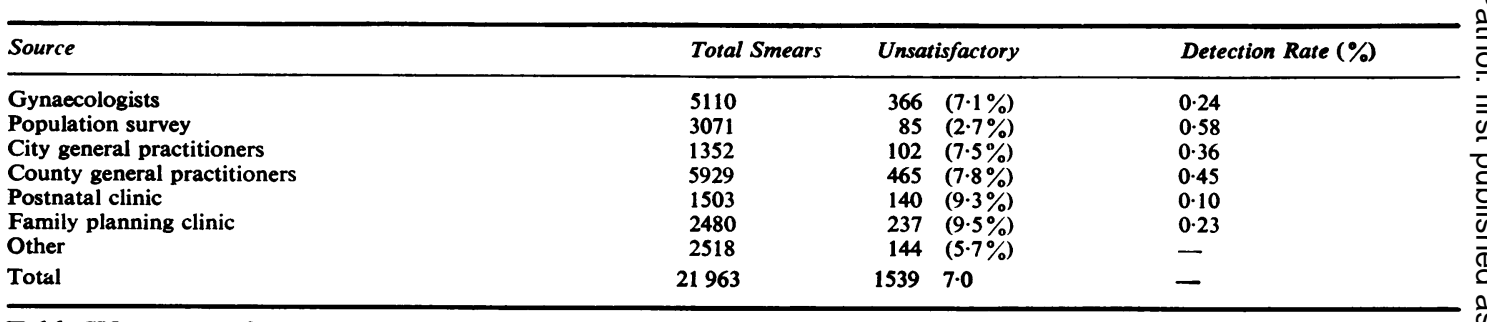

Table IX Unsatisfactory rate and detection rate compared by source of smears $(n=21963)$ (Aberdeen)

of doctors on rota at these clinics. The lowest unsatisfactory rates and the highest detection rates came from a population survey group in which the same doctor collected and examined the smears. However, the detection rates in the series cannot be compared as each group varies for age and parity.

The screener is also responsible for the primary detection of any abnormal cells in a smear. In the Christie Hospital series 0.6 per 1000 cases, ie, $6 \%$ of smears containing identifiable neoplastic cells, were missed on screening. Most laboratories have some system of internal control to mitigate this problem. The usual cause is loss of concentration due to fatigue rather than inability to recognize abnormal cells. A review of cases in which cells have been missed shows that they are usually smears with heavy inflammation, when greater alertness is needed or, paradoxically, thin clean smears. In the latter case it seems likely that there is a false sense of security that this is an easy smear and screening is done too quickly. Long hours at the microscope are fatiguing and no screener should be pressed to work faster than her optimum speed. It is also necessary to allow for short rest breaks. When technicians work full time in cytology it is inadvisable for them to spend the whole day at the microscope; it is better if they can spend part of the time on other duties. In addition to care for the wellbeing of the screener, various methods of double screening have been suggested: in some laboratories all smears are screened twice. This needs either a very large staff or very fast screening which is perhaps self-defeating.

There has been an argument for instituting a $10 \%$ rescreening check on negative smears and this has been the accreditation requirement of the American Center for Disease Control and the American Society of Cytology.

Dr M. R. Melamed in his Presidential Address to the American Society of Cytology has demonstrated that to detect a screener with a more than $10 \%$ failure rate and reading over 10000 smears per year, then with a positive smear rate of 5 per 1000 population, it would take 13 years, and if the positive rate were 1 per 2000 (which is happening in rescreening of populations at yearly intervals) then it ? could take 66 years to identify an unreliable screener $N$ (Melamed, 1973).

In a large screening laboratory it might be possible to use the method advocated by Dr M. Rodney of the Cancer Screening Service, California (Rodney, 은 1972). He recycles the abnormal smears from the previous day into the current day's workload. A graph composed of the positive discriminative $\mathbb{\Phi}_{\overparen{\infty}}$ performance rate (PDP) and the code grade of each screener is printed out from the computer data and posted on the notice board. This laboratory screens 3000 smears per day and there are $38 \%$ screeners, so that it is easy to arrange that a sme will not be rescreened by the same techniciar. Although less easy to carry out, a somewhat simil practice could be established even in the small hospital laboratory (Rodney, 1973).

A common and practical approach to rescreening in this country is to select cases which are suspect because of the clinical history, signs, or symptoms. These are usually cases with intermenstrual, postcoital, or postmenopausal bleeding. Smears from such patients are rescreened by a more senior person, medical or technical; this results in a rescreening load of well over $10 \%$ in a hospital laboratory.

\section{INTERPRETATION}

The recent WHO publication on 'Cytology of the female genital tract' (Riotton and Christopherson, 1973) has made explicit the trend to interpret the morphology of single cells in terms of disease processes. This can be done with surprising accuracy when the cytopathologist continues to educate himself by correlating the appearance of cells found in the smear with cells in the tissue section. Even when cells from the lesion are on the slide and identified by the screener, $100 \%$ accuracy is 0 not possible. This is partly because there are also problems in histological diagnosis and partly because infection or cellular degeneration in the smear can produce effects on cellular morphology which cause errors of interpretation. It is for this 
reason that the present system of differential coding of expected neoplastic states is used on the national cytology form, thus: unsatisfactory, negative, mild dysplasia, severe dysplasia/carcinoma in situ, carcinoma in situ/invasive cancer, ? glandular neoplasia. It is agreed that severe dysplasia and carcinoma in situ are often inseparable and the diagnosis of early invasion cannot be more than $90 \%$ accurate even in the most experienced hands. The finer points are, of course, presented in the uncoded report. These difficulties are demonstrated further by the report of Reagan and Patten (1962) on 137 patients with histologically proven carcinoma in situ. In these patients the cytology showed that $97.8 \%$ had significant and arresting cytological abnormalities and $2.2 \%$ were unsatisfactory. Of the satisfactory smears, $90.0 \%$ were correctly diagnosed as carcinoma in situ and $10.0 \%$ were either over- or underdiagnosed.

Any analysis of the accuracy of cytology reporting is monitored by the histological report and this is also a subjective discipline. Correlation will be closest if cytology and histology are reported by the same person, but then there is danger of individual bias occurring. The greatest disparity is found when related histology is reported by a number of laboratories, none of which is in close contact with the cytology laboratory. Problems arise because biopsy material can be inadequate. This was found in $8.5 \%$ of the cases reviewed by Govan, Haines, Langley, Taylor, and Woodcock (1966). In addition there was some divergence of opinion between the views of the panel and the views of the submitting pathologist. The variation in opinion between pathologists reporting on abnormalities of cervical epithelium is also a problem (Holmquist, McMahan, and Williams, 1967). Cocker, Fox, and Langley (1968) compared the opinions of three pathologists working in the same laboratory and using the same diagnostic criteria. They also found a 'drift' when the reports of one of the pathologists were compared with his reports on the same material after an interval of time.

Discrepancies between cytology and histology can also arise when the lesion is small. In these cases it is possible that the abnormal area is not present in any of the sections examined. This was found by Nichols, Boyes, and Fidler (1968) when they reviewed material from the British Columbia series by cutting further sections from blocks already made. They studied 105 cases with an average of 12 blocks per cone biopsy in which one section per block had been examined. There was an increase in the stage of the disease in $17 \%$ of cases when a further five sections were cut from each block. Consequently, it can be a valuable exercise for the histopathologist as well as the cytopathologist, to make a careful correlation of cytology and histology reports.

At St Mary's Hospital, Manchester (E.B.B.), the bulk of the cervical cytology comes from patients attending the hospital clinics, and the histology is reported in a closely linked department by a consultant other than the cytopathologist. Cervical smears are reported to indicate the expected histopathology, and reports of lesions of squamous epithelium fall into one of the following categories: (1) invasive squamous cell carcinoma; (2) borderline invasion/carcinoma in situ or suspicious of invasion; (3) carcinoma in situ; (4) borderline carcinoma in situ/dysplasia; (5) dysplasia; and (6)' borderline' dysplasia/benign lesion.

This method allows for precise correlation with the histological report. When discrepancies occur, both cytological and histological material is reviewed and errors in interpretation are identified. In some cases, examination of further sections demonstrates the presence of a more advanced abnormality, while in others loss of epithelium from the cervix prevents a final diagnosis being made. An attempt is always made to find the abnormal cells seen in the smear in their place in the histological pattern. In addition to promoting a detailed study of cellular morphology, the exercise as a whole indicates the problem areas in diagnosis.

During the years 1970 to 1972 , a total of 40892 cervical smears were examined and in 388 specimens, in which some degree of abnormality was reported, histology was available. The cytohistological correlation of these cases, which includes 12 cases wrongly reported as negative, is shown in table $X$. In table $X$ the central zone shows the cases in which the cytological diagnosis is considered to be acceptable, while in the upper zone the lesion was underestimated and in the lower zone overestimated.

It is of interest to study the areas in which errors are most likely to occur (table XI). Invasive carcinoma was underestimated in nine $(11.5 \%)$ smears, but in four of these the cytological report indicated carcinoma in situ. There appears to be a high rate of overestimation of benign lesions as this occurred in 41 cases (39\%). However, 34 of these were thought to have dysplasia of some degree, and as the interval before surgery was sometimes as long as two years the possibility of regression cannot be excluded; surgery was not necessarily due to the abnormal cytology report. In other cases the abnormal smear was reported during pregnancy and some of these women had had an intervening negative smear. The distinction between carcinoma in situ and dysplasia presents the biggest problem, and it is, of course, in this area that there is the most variability in reporting between histopatholo- 


\begin{tabular}{|c|c|c|c|c|c|c|c|c|}
\hline \multirow[t]{2}{*}{ Histology } & \multirow{2}{*}{$\begin{array}{l}\text { No. } \\
\text { of } \\
\text { Cases }\end{array}$} & \multicolumn{7}{|l|}{ Cytology } \\
\hline & & $\begin{array}{l}\text { Squamous } \\
\text { Cell } \\
\text { Carcinoma }\end{array}$ & $\begin{array}{l}\text { Borderline } \\
\text { Squamous } \\
\text { Cell or } \\
\text { Carcinoma } \\
\text { in Situ }\end{array}$ & $\begin{array}{l}\text { Carcinoma } \\
\text { in Situ }\end{array}$ & $\begin{array}{l}\text { Borderline } \\
\text { Carcinoma } \\
\text { in Situ or } \\
\text { Dysplasia }\end{array}$ & Dysplasia & $\begin{array}{l}\text { Borderline } \\
\text { Dysplasia or } \\
\text { Benign } \\
\text { Tumour }\end{array}$ & Negative \\
\hline Squamous cell carcinoma & 78 & 44 & 25 & 4 & 2 & 1 & 1 & I \\
\hline Carcinoma in situ & 91 & 3 & 14 & 40 & 17 & 12 & 1 & 4 \\
\hline Dysplasia & 126 & 1 & 3 & 18 & 33 & 59 & 5 & 7 \\
\hline Benign & 105 & 0 & 1 & 1 & 5 & 34 & 64 & - \\
\hline Total & 400 & 48 & 43 & 63 & 57 & 106 & 71 & 12 \\
\hline
\end{tabular}

Table X Comparison of histology and cytology reports (St Mary's Hospital, Manchester 1970-1972) on lesions of squamous epithelium ${ }^{1}$

${ }^{1}$ The central zone indicates cases with an acceptable cytological diagnosis. Cases in the upper zone were underestimated, and cases in the lower zone were overestimated.

\begin{tabular}{|c|c|c|c|}
\hline Histology & $\begin{array}{l}\text { No. } \\
\text { of } \\
\text { Cases }\end{array}$ & Overestimated & Underestimated \\
\hline $\begin{array}{l}\text { Squamous cell carcinoma } \\
\text { Carcinoma in situ } \\
\text { Dysplasia } \\
\text { Benign }\end{array}$ & $\begin{array}{l}78 \\
91 \\
126 \\
105\end{array}$ & $\begin{array}{r}-3(3.3 \%) \\
22(17 \cdot 4 \%) \\
41(39 \cdot 0 \%)\end{array}$ & $\begin{array}{r}9(11.5 \%) \\
17(18.6 \%) \\
7(5.5 \%) \\
-\quad\end{array}$ \\
\hline Total & 400 & $66(16.5 \%)$ & $33(8.2 \%)$ \\
\hline
\end{tabular}

Table XI Percentage of cases overestimated and underestimated (St Mary's Hospital, Manchester)

gists (Cocker et al, 1968). In this series the tendency was to underestimate carcinoma in situ and to overestimate severe dysplasia. The advantage of the association of these two lesions in the coding of the national form is made apparent. In any study of quality control throughout the country it is important to know how much variation there is in reports given on the same smear from one cytology laboratory to another. One of us (D.M.D.E.) circulated 100 smears to five well established centres in England and Wales for a report using the following codes: normal, atypical, dyskaryotic, suspicious of malignancy, positive for malignancy (Evans and Sanerkin, 1970). In summary, the results, analysed in many different ways, showed a significant understatement, ie, more than one remove in grade code, for the five centres of 3,10 , 13,26 , and $26 \%$, demonstrating a wide scatter even between experienced units. A more recent survey where each of six centres provided 20 smears has resulted in much closer agreement in five of the centres when using (a) the standard National Health Service cytology report codes, (b) the centre's own terminology, and (c) recommended recall time. Here, there were fewer than $3 \%$ false negative results and not more than $1.7 \%$ false positive results. (A more detailed report of this is presented elsewhere in thejournal.) This demonstrates how a form of quality control can be effected between different centres, but it must be apparent that these test smears will get the full attention of the most expert in such units and in no way assesses the average quality of the primary screener employed there.

\section{Conclusions and Recommendations}

1 The work from the Christie Hospital indicates that a single smear test is not sufficiently reliable. Although one third of the cases were missed due to human error in the laboratory, two-thirds were missed because of failure of collection. Some of these cases might be due to a poorly taken smear but others would be due to biological variation over which there is no control. At present the national recall system allows five years before a repeat smear is advised and the concept of requiring a second smear, to check the first, before inclusion in the five-year recall list is too uneconomic to be acceptable, especially in the under-25s where they would 오 be more likely to occur. Alternatively and preferably, $\rightarrow$ a three-year recall would spread the screening net over the intervening years and provide an improved $N$ cover.

2 The laboratory has an important function in monitoring the quality of smears received from $\omega$ different sources. When there is a high incidence $\bar{\sigma}$ of unsatisfactory smears, discussions on methods $O$ of collection would be of value. It is also possible $\mathbb{\Phi}$ that the shape of the spatula can be improved.

3 Perhaps the most basic requirement is one of $\underline{T}$ professional bodies instituting certain codes of $\frac{\vec{P}}{\vec{D}}$ practice for both individuals and laboratories. These 
codes are currently being discussed to achieve general agreement and acceptance.

4 All laboratories should make use of some form of internal quality control.

4a Control of screening would be covered if the screener were required to record essential data such as cellularity of specimens, the existence of blood, pus, or mucus, the presence of endocervical columnar cells and of metaplastic or deep squamous cells. One centre (O.A.N.H.) makes use of the local code boxes on the national form for this purpose and the data, together with the clinical history, allow a quick assessment of the need for double screening or further investigation. Selection of cases on such criteria is accepted as the most economical way of rescreening a proportion of negative smears. The ability of the screener to recognize abnormal cells can also be checked by recycling previous abnormal smears in a manner similar to that followed by the Cancer Screening Service, California (Rodney, 1973). This is particularly applicable in large laboratories.

$4 \mathrm{~b}$ Constant correlation with histology reports is essential and when discrepancies are found the cytological and histological material should be reviewed by the cytotechnician, the cytopathologist, and the histopathologist. Such cases form the basis for discussion sessions which are important in maintaining a high standard of screening and interpretation. It is also advisable to analyse the results of the laboratory every year so that the performance can be compared from year to year. This will also show if there is any 'drift' in the quality of reporting and indicate in which areas the problems of over- and underdiagnosis are most likely to arise in that laboratory.

5 The question of external nation-wide quality control presents further problems. One of the most fundamental difficulties is that the cytology reports in any centre will tend to reflect the attitude of the histopathologist who reports the related tissue. This means that any exchange of cytological material between laboratories should also include an exchange and review of the relevant histology sections between the histopathologists concerned.

$5 \mathrm{a}$ Some estimate of the acceptability of the work of any cytology laboratory in its own hospital could be made if a detailed analysis such as is given in tables IX and $\mathrm{X}$ were submitted to a supervisory committee. Each laboratory would be responsible for recognizing whether errors were due to quality of material, screening, or interpretation and for taking steps to remedy matters where possible.

$5 \mathrm{~b}$ Another possibility would be for laboratories to submit specified smears and their reports, eg, the fifth normal and first abnormal smear test received in a given week or month to a central distributing laboratory which would then circulate these smears and reports, either to a central panel of cytopathologists, or to other laboratories, under a code number. In the latter instance, a rotating panel of cytopathologists (who would serve for at most three years) would adjudicate when there were discrepancies in reporting. This might be most satisfactory if done on a regional basis in order to spread the additional work load. Circulation of a number of stained unknowns heavily loaded with abnormal smears in the manner of surveys carried out by one of us (D.M.D.E.) would achieve a measure of comparative final assessment of a test but does not assess the efficiency of detection in a laboratory. As a unifying and educative procedure this has something to commend it, again, preferably conducted on an informal basis, and necessarily limited to small groups of laboratories due to the deterioration in smear quality which occurs.

5c The issue of unknowns to laboratories: it would be difficult to collect enough abnormal material in the way of duplicate smears to send the paired, unstained material to all laboratories to be stained, screened, and reported. This would allow control of the quality of staining but only in the broadest sense because of the range of individual preference. In practice, the likelihood of an unsatisfactory second scrape sample and the method of introduction of the test material make this proposal unworkable.

The last two methods of external control also have the disadvantage that they would not be a true indication of work done in the laboratory because any material which was known to be going outside for review would, very naturally, receive more time and attention than might be possible for every routine smear. Nevertheless such a practice would in itself help to raise standards. Any attempt at submitting unknown, unstained material via a local general practitioner or clinic would only result in embarrassment and annoyance when the normal follow-up enquiries from the laboratory were made on a suspect case.

\section{References}

Achenbach, R. R., Johnstone, R. T., and Hertig, A. T. (1951). The validity of vaginal smear diagnosis in carcinoma in situ of the cervix. Amer. J. Obstet. Gynec., 61, 385-392.

Barr, W. T., Powell, D. E. B., and Raffan, J. B. (1970). Cellular contamination during automatic manual staining of cytological smears. J. clin. Path., 23, 604-607.

Butler, E. B. (1973). Problems in diagnostic cytology. In Postgraduate Obstetrical and Gynaecological Pathology, edited by H. Fox and F. A. Langley, pp. 281-291. Pergamon Press, Oxford.

Cocker, J., Fox, H., and Langley, F. A. (1968). Consistency in the histological diagnosis of epithelial abnormalities of the cervix uteri. J. clin. Path., 21, 67-70. 
Cuyler, W. K., Kaufmann, L. A., Carter, B., Ross, R. A., Thomas, W. L., and Palumbo, L., (1951). Genital cytology in obstetric and gynecologic patients: a four year study. Amer. J. Obstet. Gynec., 62, 262-278.

Evans, D. M. D., and Sanerkin, N. G. (1970). Cytology screening error rate. In Cytology Automation: Proceedings of the second Tenovus Symposium, Cardif, 1968, edited by D. M. D. Evans, pp. 5-13. Livingstone, Edinburgh.

Fidler, H. K., Boyes, D. A., and Lock, D. R. (1957). Intra-epithelial carcinoma of the cervix: 214 cases, with emphasis on investigation by cytology and cone biopsy. Canad. med. Ass., 77, 79-85.

Friedell, G. H., Hertig, A. J., and Younge, P. A. (1960). Carcinoma in situ of the Uterine Cervix, p. 102. Thomas Springfield, Illinois.

Frost, J. K. (1967). In Novak's Gynecologic and Obstetric Pathology, 6th ed., edited by E. R. Novak and J. D. Woodruff, p. 664. Saunders, Philadelphia and London.

Frost, J. K. (1969). Diagnostic accuracy of 'cervical smears'. Obstet. Gynec. Surv., 24, 893-908.

Gondos, B., Marshall, D., and Ostergard, D. R. (1972). Endocervical cells in cervical smears. Amer. J. Obstet. Gynec., 114, 833-834.

Govan A. D. T., Haines, R. M., Langley, F. A., Taylor, C. W., and Woodcock, A. S. (1966). Changes in the epithelium of the cervix uteri. J. Obstet. Gynaec. Brit. Civlth, 73, 883-896.

Graham, R. M., and Meigs, J. V. (1949). The value of the vaginal smear. Amer. J. Obstet. Gynec., 58, 843-850.

Holmquist, N. D., McMahan, C. A., and Williams, O. D. (1967). Variability in classification of carcinoma in situ of the uterine cervix. Arch. Path., 84, 334.

Husain, O. A. N. (1970). The irrigation smear: a comparative trial of vaginal irrigation pipette and spatula smears in the detection of cervical cancer. Amer. J. Obstet. Gynec., 106, 138-146.

MacGregor, J. E., Fraser, M. E., and Mann, E. M. F. (1966). The cytopipette in the diagnosis of early cervical carcinoma. Lancet, 1, 252-256.

Melamed, M. R. (1973). Presidential Address, 20th Annual Scientific Meeting, American Society of Cytology. Acta cytol. (Philad.), 17, 285-288.

Nichols, T. M., Boyes, D. A., and Fidler, H. K. (1968). Advantages of routine step serial sectioning of cervical cone biopsies. Amer. $J$. clin. Path., 49, 342-346.
Reagan, J. W., and Hicks, D. J. (1953). A study of in situ and squamouscell cancer of the uterine cervix. Cancer (Philad.), 6, 1200-1214.

Reagan, J. W., and Patten, S. F. (1962). Cytology and its office 으. application as viewed by the pathologist. Clin. Obstet. Gynec., $5,167-178$.

Richart, R. M. (1964). Evaluation of the true false negative rate in cytology. Amer. J. Obstet. Gynec., 89, 723-726.

Richart, R. M., and Vaillant, H. W. (1965). The irrigation smear: 흐 false negative rates in a population with cervical neoplasia. $\frac{\mathcal{O}}{}$ J. Amer. med. Ass., 192, 199-202.

Riotton, G., and Christopherson, W. M. (1973). WHO International $\mathrm{Q}$ Histological Classification of Tumours, No. 8. World Health Organization, Geneva.

Rodney, M. B. (1972). Data control and quality of the human cyto- $\overrightarrow{0}$ screening function. Hlth Lab. Sci, 9, 215-224.

Rodney, M. B. (1973. Personal communication.

Scheffey, L. C. (1949). The value of the vaginal smear: a discussion of $\mathcal{O}$ the article by Graham and Meigs. Amer. J. Obstet. Gynec, $58,847-849$.

Silbar, E. L., and Woodruff, J. D. (1966). Evaluation of biopsy, cone, iv and hysterectomy sequence in intra-epithelial carcinoma of the $V$ cervix. Obstet. and Gynec., 27, 89-97.

Simon, T. R., Durfee, G. R., and Ricci, A. (1955). Quoted by Koss, L. G. In Diagnostic Cytology and its Histopathologic Bases, 2nd ed., p. 292. Pitman, London, 1968.

Soule, E. H., and Dahlin, D. C. (1960). Cytodetection of pre-clinical O carcinoma of the cervix: 12 years' experience with initial screening and repeat cervical smears. Proc. Mayo Clin., 35, 508-513.

Wied, G. L. (1955). Importance of the site from which vaginal cytologic smears are taken. Amer. J. clin. Path., 25, 742-750.

Wied, G. L., and Bahr, G. F. (1959). Vaginal, cervical and endocervical cytologic smears on a single slide. Obstet. and Gynec., $\mathbb{D}$ 14, 362-367.

Yule, R. (1973). The prevention of cancer of the cervix by cytologigl $\overrightarrow{0}$ screening of the population. In Cancer of the Uterine CervQ, V edited by E. C. Easson, pp. 11-25. Saunders, Philadelphia a London. 